Portland State University

PDXScholar

\title{
Language in the Korean Workplace: an Analysis of Hierarchical Language Use in the Drama Misaeng
}

Jessie Nicole McNeill

Portland State University

Follow this and additional works at: https://pdxscholar.library.pdx.edu/honorstheses

\section{Let us know how access to this document benefits you.}

\section{Recommended Citation}

McNeill, Jessie Nicole, "Language in the Korean Workplace: an Analysis of Hierarchical Language Use in the Drama Misaeng" (2017). University Honors Theses. Paper 438.

https://doi.org/10.15760/honors.435

This Thesis is brought to you for free and open access. It has been accepted for inclusion in University Honors Theses by an authorized administrator of PDXScholar. Please contact us if we can make this document more accessible: pdxscholar@pdx.edu. 
Language in the Korean Workplace: An Analysis of Hierarchical Language Use in the Drama Misaeng (미생)

\author{
by \\ Jessie Nicole McNeill
}

An undergraduate honors thesis submitted in partial fulfillment of the requirements for the degree of

Bachelor of Arts

in

University Honors

and

Anthropology

Thesis Adviser

Ms. KyungAh Yoon

Portland State University

2017 
I. Abstract

II. Introduction

A. The Korean language

B. Historical ideologies in Korea

1. Confucianism and neo-Confucianism

2. Hierarchy

C. Thesis

III. Hierarchy in the Korean Language

A. Research trends

B. Formality and speech styles

IV. Korean Workplace Culture

A. Cultural values in the workplace

1. Collectivism

2. Kibun and inhwa

V. Why Drama? Why Misaeng?

A. Researchers using dramas as source material

B. Misaeng

1. Background

2. Reviews/popularity in Korea

VI. Research Methods

A. Data collection

B. Transcription, translation and analysis

VII. Situational Analysis

A. Analysis methods

B. Regular speech patterns in Misaeng

1. Between co-workers of the same rank

2. Between co-workers of different rank

C. Request/favor strategies

1. Between co-workers of the same rank

D. Refusal strategies

1. Between co-workers of different rank

E. Style switching and other linguistic strategies

1. Between a client and employee

\section{Conclusion}

\section{References}




\begin{abstract}
The influences of Confucian and neo-Confucian values can be seen in contemporary Korean culture and language (Seth 2016). The Korean language is hierarchical, meaning that the language demonstrates a clear social hierarchy between speakers through the use of various determined linguistic techniques (Agha 1998). Native Korean speakers employ a combination of speech styles and levels, honorifics, politeness and humbling strategies to convey their reception of the hearer's social location in the hierarchy (Choo 2006). The environment of the Korean workplace is shaped by these cultural values with very apparent social stratification by rank(Lee 2012). The emphasis on social stratification makes the Korean workplace a great environment to study the use of various speech forms in hierarchical relationships. This paper will analyze the usage of speech styles in hierarchical relationships in the Korean workplace by examining conversations in the Korean office drama Misaeng.
\end{abstract}

\title{
Introduction
}

\section{The Korean language}

In 1443-1444 CE, the fourth monarch of the Korean Choson dynasty created Han-geul (한글), a Korean alphabet system with individual symbols for each of the consonants and vowels in the Korean language. As of 2014, around 81 million people worldwide were estimated to speak the Korean language. Due to the effects of the Korean war, the widespread migration of people from the Korean peninsula, and regional dialectal differences within the Korean peninsula, the language has been adapted and can vary 
based on region (Brown 2015). For the purposes of this project, the paper will focus on the South Korean standardized form of the Korean language.

\section{Thesis}

This thesis paper will analyze the Korean language. Specifically, the paper will look at the way that speech styles are used in hierarchical relationships in the Korean workplace. In addition to looking at the linguistic aspect, this paper will also consider the cultural and ideological influences on the Korean language and how these neo-Confucian values influence the environment of the modern Korean workplace. Finally, the thesis will examine patterns of speech style usage and other linguistic strategies employed by characters in specific hierarchical work relationships in the office drama Misaeng (미생). Excerpts from conversations between characters that demonstrate these patterns will be used to demonstrate the use of speech styles in different situations and analyzed for variance based on the hierarchical relationship between the characters in the exchange.

\section{Historical ideologies in Korea}

\section{Confucianism and neo-Confucianism}

Along with many parts of East Asia, South Korean culture was significantly influenced by the teachings of Confucianism. Confucius (Kung Fu-Tzu) taught in China around 500 BCE and developed a philosophy based on a system of order. Confucius determined five relationships of key importance: ruler-subject, parent-child, brother-sister, friend-friend (Lee 2012). Based on these relationships, he prescribed five moral ideals:

"(1) Justice and righteousness should mark the relations between sovereign and subject; (2) There should be proper rapport between father and son; (3) Separation of function between husband and wife; (4) The younger should give precedence to the elder; and (5) Faith and trust should reign over relationships between friends" (Lee 2012). 
South Korea was influenced by Confucian ideas regarding family and relationships since the Three Kingdoms Era. In the Choson dynasty, neo-Confucianist influences became widespread in Korean culture (Seth 2016). The impact of Confucianism and neo-Confucianism on Korean culture has created a strict social and linguistic hierarchy in which linguistic style is based on the relationship between the listener and hearer and the hearer's social status (ie. age, gender, job, relationship) (Seth 2016) (Choo 2006).

\section{Hierarchy}

South Korea is a historically hierarchical society in which individuals use a combination of different speech forms, honorifics, and humbling strategies to convey the hierarchical, social position of the speaker and listener (Cho 2006). These strategies can be used separately or in congruence to convey the speaker's intended message and Brown (2015) argues that the connection between these strategies and culture must be examined. The following chapter will examine the different linguistic strategies typically employed by native Korean speakers in South Korea, focusing on the use of speech styles.

\section{Hierarchy in the Korean Language}

\section{Research trends}

Before analyzing the use of Korean speech styles in hierarchical relationships, the traditional and recent trends in Korean formality language research should be considered. According to Brown (2015), Korean speech research has historically separately analyzed speech style and honorifics without considering the intersections of other linguistic and non-linguistic strategies. Recent research has begun to consider formality use in concurrence with cultural politeness ideologies, such as the maintenance of social 
hierarchy (Brown 2015). However, Brown (2015) proposed that future research should consider honorific use holistically by examining the intersection between honorific and speech style use and other politeness techniques, language choice, and nonverbal behavior. This thesis will focus on the ways that speech styles are used in hierarchical relationships. However, per Brown's (2015) suggestion, other language choices, techniques, and non-verbal cues will also be considered in the analysis of each situation.

\section{Formality and speech styles}

Korean is defined as an SOV (subject object verb) language, but this is misleading. Full sentences in Korean must always end with the verb, but the subject and object are somewhat flexible in location and sometimes can be omitted as well (Cho 2006).

The Korean language has six different styles of speech as defined by Choo (2006), Brown (2015), and Cho (2006). Speech style usage is uncommon in most world languages. In Korean, these speech styles are achieved through different conjugated verb endings which are used, at least basically, due to the speaker's perception of the listener's hierarchical position compared to their own social position (Brown 2015). While this is the basic function of various Korean speech styles, speech style and other honorific strategies may be used differently in certain situations to convey refusal, requests, disrespect, and sarcasm (Brown 2013). The additional functions of speech style will be discussed later in this paper.

Although contemporary literature recognizes the similar Korean speech styles and their functions, the English titles used to refer to these speech styles vary based on the author's preferences. For the purposes of this paper, Choo's (2006) terminologies for 
speech style will be used to analyze the Korean language and conversations in Misaeng.

Choo (2006) divides the four main speech styles into "honorific" and "non-honorific" and usage based on the type of sentence the speaker is making. However, since "honorific" is a term often used in discussion of speech levels, which will not be analyzed in this paper, the terms "honorific" and "non-honorific" have been reclassified as "formal" and "informal" for the purposes of this paper.

\section{Table 1 (Choo 2006)}

\begin{tabular}{|c|c|c|c|c|}
\hline \multirow{2}{*}{ Sentence Type } & \multicolumn{4}{|c|}{ Speech Style } \\
\cline { 2 - 5 } & Heavily formal & Gently formal & $\begin{array}{c}\text { Soft } \\
\text { casual }\end{array}$ & $\begin{array}{c}\text { Non-conversational } \\
\text { / plain casual }\end{array}$ \\
\hline Declarative & (seu)b-ni-da & (eo/a/e)-yo & eo/a/ae & (nu)n-da, da \\
\hline Interrogative & (seu)b-ni-kka & (eo/a/e)-yo & eo/a/ae & (eu)-ni, (eu)n-ya \\
\hline Propositive & (eo)sib-si-da & (eo/a/e)-yo & eo/a/ae & ja \\
\hline Imperative & (eo) sib-si-o & (eo/a/e)-yo & eo/a/ae & ora/ara \\
\hline
\end{tabular}

*original table converted from $\mathrm{M}-\mathrm{R}$ romanization to the revised Korean government form for handout;

**Also two minor informal speech styles; used by older generation speakers: "blunt" style (-o; -sso) and "familiar" style (-ne; -ge; -se)

*** Plain casual/non-conversational: used for casual language; also used for formal writing

Contemporary Korean employs the four main speech styles, illustrated above, frequently based on the perceived hierarchical position of the other individual. The two other speech styles are often referred to as "blunt" styles and Choo (2006) states that these 
are minor speech styles that are commonly used by elder Koreans but rarely used by younger Korean speakers. Native korean speakers will choose which speech style to use based on the relationship, age, and perceived power of the listener (Cho 2006). When speaking to strangers or non-close friends, either the heavily formal -습니다 (seu)b-ni-da or gently formal -요 ((eo/a/e)-yo) forms are usually considered polite. Informal styles often imply either closeness and intimacy or that the listener is lower in the social hierarchy than the speaker. However, while formal forms imply high levels of respect, they also indicate distance between the speaker and the listener. Therefore, use of the formal styles with intimate friends can create distance in personal relationships by indicating distance between individuals in close relationships (Choo 2006).

\section{Korean Workplace and Culture}

\section{Cultural values in the workplace}

\section{Collectivism}

Western cultures are often termed individualist cultures which "emphasize... 'I' consciousness, autonomy, individual initiative, and right to privacy" (Seo 2012: 419). In comparison, East Asian cultures are referred to as a collectivist cultures. Collectivism is defined by Seo (2012: 419) as “emphasiz[ing]: 'we' consciousness, collective identity, duties, and group decisions." Collectivist ideals can affect the cultural expectations and behaviors of employees in the workplace (Seo 2012). One of the ways through which collectivist ideals are represented in the workplace is through the importance of kibun and inhwa (Lee 2012).

Kibun and Inhwa 
Two of the most important principles to understanding contemporary Korean culture in the workplace are the neo-Confucian values of kibun and inhwa. Kibun lacks an exact English translation, it roughly translates to "a mood or feeling of balance and good behavior" (Lee 2012). To maintain this neo-Confucian value, co-workers tend to avoid disrupting the kibun of their colleagues by avoiding direct refusals or publicly criticizing one another. Korean's use a concept termed nunchi to protect other individuals' kibun. $N u n c h i$ is the way in which you look at someone closely to determine what a person really means, beneath the surface of a statement. Nunchi is used to understand a person's feelings without asking so that the individual does not experience a loss in kibun (Lee 2012).

Inhwa translates into "harmony" in English. The neo-Confucian value of inhwa focuses on maintaining the harmony between individuals, particularly those who are socially stratified (ie. individuals in different hierarchical positions). Due to the pervasiveness of inhwa in the work environment, colleagues are expected to maintain harmony with one another. The Korean workplace expects superiors to care for the health and overall well-being of their inferiors. Conversely, inferior employees are expected to obey and respect their superiors wishes and avoid conflict (Lee 2012).

\section{Why Drama? Why Misaeng?}

\section{Researchers using drama as source material}

Television shows create a fictional discourse which is influenced by advertising and the political and social interests of the discourse's creators (Kim 1998). However, television content can still give insight into the culture of a country, it's values, and the 
effects of these values and other influences, such as globalization, on that country (Monaco 1998). The fictional reality presented in television shows can also serve to change the values of that country and push the boundaries of gender, social norms, race, and sexual identity (Barker 1999). Korean dramas, in particular, have been used by a number of researchers to consider these societal influences and effects as well as the linguistic patterns of characters.

In 1998, Do-Goan Kim (1998) completed a Masters thesis in Mass Communications on the reception of Korean dramas from 1960-1998. Kim analyzed the link between socio-political movements and other cultural changes in Korea and the content of Korean media. Through Kim's thesis, the increased influence and prevalence of Korean dramas in South Korea is demonstrated. Equally, the relationship between the representation of contemporary Korean values in dramas and positive South Korean audience reception was demonstrated (Kim 1998).

\section{Misaeng}

\section{Background}

Misaeng follows the experiences of different characters within a large corporation called One International. Although the President of the company is represented as the foremost authority, he is only present in a few scenes. In the majority of scenes, the CEO is shown at the top of Misaeng's workplace hierarchy. Under the direction of the CEO, major operations of the company are divided by floor, each floor led by a floor boss. Within each floor there are teams which focused on specific areas of need (such as sales team, steel team, etc.). Each team works independently on projects, but also in congruence 
with other teams on that floor or other floors. Each team consists of between three to five characters. Each team consists of (in order of hierarchical status) a team boss, an employee or employees, and an intern. At one point in the drama, the interns undergo a process which elevates their title to temporary employee in training, but they remain in the same hierarchical position, so for the purpose of this paper they will be referred to as interns throughout the paper (Misaeng 2014). Analysis of this drama will be focused on the relationships between the characters with the most interaction, including the CEO, floor boss, team boss, employees, and interns.

\section{Reviews/popularity in Korea}

Kim (1998) concluded that the audience's reception of a television discourse, or korean drama, can indicate whether or not the drama accurately expresses the reality of the society. Misaeng was well received by the South Korean population. The drama's finale had a record breaking 8.2 percent viewership compared to the typical expectations for Misaeng's time slot. The Korea herald attributed Misaeng's popularity to the drama's accurate portrayal of the reality of contemporary South Korean office life and the Korean audience's growing frustrations with the pressures of Korean workplace (Sung-Mi 2015). One South Korean viewer, Han Jeong-taek stated “When I watch 'Misaeng,' I feel like I am not alone in suffering office hardships like long hours, a mountain of work and workplace politics... The drama is very realistic, maybe more so than reality... I empathize with the characters in the drama. Their struggles feel like my own" (Sung-Mi 2015). Positive reception of Misaeng by South Korean viewers, like Han Jeong-taek, and positive South Korean news source's positive reviews likely indicate that Misaeng creates 
a fictional discourse through which the setting and interactions in Misaeng represent the reality of South Korea's work environment.

\section{Research Methods}

\section{Data collection}

In the Korean drama Misaeng, most of the conversation occurs in a corporate, workplace environment in South Korea. Language analysis of this drama is focused on the communication between individuals from both the same and different hierarchical levels in the workplace. The first step in analyzing Misaeng was determining which characters' interaction should be focused on.

To determine this, Misaeng was first watched with subtitles in it's entirety, for fuller comprehension of the plot. While watching the drama, notes were taken on the number of interactions between different characters and the linguistic differences between these characters. The way the corporate environment of Misaeng operated was also noted.

Based on the frequency of interaction between different individuals in Misaeng, conversations in Misaeng were divided into the seven main hierarchical relationships for analysis. The relationships were: same level employees (i.e. boss-boss, intern-intern); CEO-team boss; team boss-floor boss; team boss-employee; team boss-intern; employee-intern; and client-employee. Focusing on these defined hierarchical relationships allows for an analysis of the language used in Misaeng's workplace hierarchy.

After the first viewing of Misaeng, scripts in the Korean written language Han-geul (한글) for episodes 1-11 were obtained. After deciding to focus on these first 
eleven episodes, episodes 1-11 were rewatched without subtitles. While watching the interaction in each episode of Misaeng, the script was followed. Notes were taken on the scripts of each episode about the speech styles and tone of characters in each of the six relationships throughout the episode, as well as the situation of each episode. The patterns of speech between individuals in these relationships were noted and the conversations where characters' linguistic patterns were inconsistent with their previous behavior was also noted. The speech choices of individuals were then considered based on both the situation in which they were conversing and the hierarchical relationship between the characters.

\section{Transcription, translation, and analysis}

For the purposes of this paper, excerpts from situations that demonstrated the linguistic patterns in this relationships were translated from the Han-geul script into English and romanization. English translation was done using a combination of my knowledge of Korean, Naver Online Dictionary (네이버), a well-reputed Korean online dictionary app developed in South Korea, and traditional book Korean-English dictionaries. Translations were then checked and revised by a native Korean speaker from South Korea and a Portland State University student, colleague, and friend, Sunho Kim (김선호).

There are three common styles of Han-geul romanization: the McCune-Reischauer system, the Yale system, and the South Korean government's revised romanization system (Sohn 2006). The romanization style used throughout this paper and in the excerpts is the revised romanization of Korean set forth by the South Korean Ministry of Culture and 
Tourism in 2000. This form of romanization was chosen since it is the most recently revised form of Korean romanization and this is the form of romanization used by the South Korean government. Although the McCune-Reischauer system of Romanization is often more common in Western literature, the system lacked phonetic representation of all of the characters in Korean. In the McCune-Reischauer system, characters such as " $\neg$ " and “ $"$ "were both represented with a "k" (Ministry of Culture and Tourism 2000:6). Although this representation fits the sound that is often heard by Westerners for these characters, the actual differences between the characters were not demonstrated in the McCune-Reischauer romanization. This lack of distinction led to inconsistencies in romanization usage between native and non-native Korean speakers within South Korea (Ministry of Culture and Tourism 2000). For these reasons, the Revised Romanization of Korean is employed in this paper. In the next chapter of this paper, the speech patterns found in Misaeng will be demonstrated through an analysis of these excerpts which have been both translated and romanized.

\section{Situational Analysis}

\section{Methods of analysis}

This section will examine various linguistic techniques and patterns shown in the hierarchical relationships in Misaeng. These techniques will be examined through excerpts from different scenes in episodes 1 through 10 of the drama. The original Han-geul script has been translated into English and romanized to make the analysis more accessible non-Korean speakers. The original Han-geul has also been included so that these findings 
are equally accessible to Korean speakers. The non-verbal stage directions are in parenthesis in Han-geul and translated into English.

In each excerpt, the speech style is included in parenthesis next to each line of romanized script. The capitalized letters in the parenthesis indicate formal (F) or informal (IF) speech style. Following the speech style in the parenthesis is the specific speech style used by the speaker. If the conversation is an incomplete sentence and there is no verb, there will be no speech style. In this case, the line of speech will not have a label for speech style.

\section{Regular speech patterns in Misaeng}

Between co-workers of the same rank

Co-workers of the same hierarchical position or rank are usually demonstrated speaking in the same speech style as the other character. These speech styles are usually the gently formal speech style or one of the informal speech styles. In the following conversation, two team bosses are speaking to each other. Go Gwajang has seen Oh Sang Sik in a meeting with their superior. Go Gwajang interprets this meeting as a demonstration that Oh Sang Sik has a desire to get himself promoted. Both characters speak in informal casual speech styles towards each other since they are the in the same rank and have a close relationship.

\section{Episode 10: Scene 39 (team boss-team boss; same rank)}

1. 고과장 야, 오과장아. 너 아까 부장님하고 뭘 그렇게 쑥덕대? ya, o-gwa-jang-a. neo a-kka bu-jang-nim-ha-go mwol geu-leoh-ge ssug-deog-dae? (IF: plain casual) Go Gwajang: Hey, Mr. Oh. What are you doing with the boss?

2. 상식 (고민 깊은 얼굴로 고과장을 본다) Sang sik: (Looks at Go Gwajang with a deep, sad face)

3. 고과장 너 요즘 부장님하고 사이 좋드라? 질투나게. neo yo-jeum bu-jang-nim-ha-go 
sa-i joh-deu-la? Jil-tu-na-ge. (IF: soft casual)

Go Gwajang: Have you been getting along with the boss lately? I feel jealous.
4. 상식
(피식 웃는)

Sang sik: (laughs)

5. 고과장 이제야 슬슬 라인의 중요성을 깨달은 거냐? 그래, 잘 생각했어. 잡을 건 잡아야지. 나 혼자 승진하면 내가 미안하잖아. 야, 적어도 부장은 달고 나 가야지. 안

그래? -je-ya seul-seul la-in-ui jung-yo-seong-eul kkae-dal-eun geo-nya? geu-lae, jal saeng-gag-haess-eo. jab-eul geon jab-a-ya-ji. na hon-ja seung-jin-ha-myeon nae-ga mi-an-ha-janh-a. ya, jeog-eo-do bu-jang-eun dal-go na ga-ya-ji. an geu-lae? (IF: soft and plain casual)

Go Gwajang: Did you finally realize the importance of rank?Yes, I thought so. I'll catch up with you. I'm sorry if I get promoted myself. Hey, hey, hey, I gotta go.Isn't it?

6. 상식 (가볍게 웃으며) 그래, 그렇지. geu-lae, geu-leoh-ji. (IF: plain casual) Sang sik: (smiling brightly) Yeah, yeah.

7. 고과장 그치. 그래야 어디 가서.. geu-chi. geu-lae-ya eo-di ga-seo.. (하는데 울리는 핸드푼. 보고 반색하며 받는다) (IF: plain casual)

Go Gwajang: Yes, where should we go? (phone rings, receiving phone call)

8. 고과장 예, 조사장님! (손으로 오과장한테 양해 구하고, 나가면서) 예, 도착하셨습니까. 예예, 지금 내려갑니다. (멀어진다) ye, do-chag-ha-syeoss-seub-ni-kka. ye-ye, ji-geum nae-lyeo-gab-ni-da. (F: heavily formal) Go Gwajang: Yes, Mr.Cho! Yes sir, yes sir, yes sir. Yes, we're going down now (Go Gwajang leaves).

Script: (Yoon-Jung 2014).

In this next conversation, some interns are speaking to one another about another character, GeuRae's, lack of qualifications for the internship, as well as their college and work experience thus far. The conversation occurs between interns and an upper division employee (Ha Daeri). For the sake of looking at hierarchical speech styles, the analysis will only focus on the conversation between the interns.

\section{Episode 1: Scene 48 (intern-intern; same rank)}

1. 이상현 우리가 여기 인턴이라도 들어오려고 얼마나 열심히 공부했어요?

대학 4년이 고동학교 연장이었다구요. 안 그래요? 장백기씨? u-li-ga yeo-gi in-teon-i-la-do deul-eo-o-lyeo-go eol-ma-na yeol-sim-hi gong-bu-haess-eo-yo? dae-hag 4nyeon-i go-deung-hag-gyo yeon-jang-i-eoss-da-gu-yo. an geu-lae-yo? Jang-baeg-gi-ssi? (F: Gently formal) I Sanghyeon: How hard have we studied in order to get a job here, even an internship? Last four years of college was like pursuing studies in high school. Don't you think so?Mr. 
Jang Baek Gi?

2. 백기 (가볍게 커피 마시며 피식 웃으며) 입시연장이었죠.

ib-si-yeon-jang-i-eoss-jyo. (F: Gently formal)

Baek Gi: (Smiling quietly while drinking a coffee) yeah, it was an extension of the college entrance exam.**

3. 석호 (한숨) 그 놈의 스펙8종 쌓느라고.. geu nom-ui seu-peg-8-jong ssah-neu-la-go.. (IF: soft casual)

Seok Ho: (sighs) In order to get the 8 specific types of qualifications

4. 이상현 (하대리 보고) 형님도 그러셨잖아요? 저 입학했을 때 형님 4학년이었죠? hyeong-nim-do geu-leo-syeoss-janh-a-yo? jeo ib-hag-haess-eul ttae hyeong-nim 4hag-nyeon-i-eoss-jyo? (F: gently formal) I Sanghyeon: Didn't you?When I entered (University) were you a senior?

5. 하대리 (웃으며 꾜덕꾜덕) 그랬지. Geu-laess-ji. (IF: soft casual) Ha Daeri: (laughing) Yeah.

6. 석호 은근 끼리끼리 동문 많네요? IT팀 이과장님은 우리 과 선밴데. eun-geun kki-li-kki-li dong-mun manh-ne-yo? ITtim i-gwa-jang-nim-eun u-li gwa seon-baen-de. (H: gently formal and $\mathrm{NH}$ : soft casual) Seok Ho: There are many groups of alumni from certain school. The IT team manager senior alumnus with me.

7. 인턴2 아, 근데 저 사람은 대체 무슨 대단한 빽일까요? 그렇게 있어 뵈진 않는데.. a, geun-de jeo sa-lam-eun dae-che mu-seun dae-dan-han ppaeg-il-kka-yo? geu-leoh-ge iss-eo boe-jin anh-neun-de.. (H: gently formal) Intern 2: Oh, but what, does that guy have a such connection? He dosen't look like...

8. 이상현 빽은 빽이고오, 액면가는 견적 딱! 나오는데 뭐, ppaeg-eun ppaeg-i-go-o, aeg-myeon-ga-neun gyeon-jeog ttag! na-o-neun-de mwo, (NH: soft casual) I Sanghyeon: Whatever connection he has, he seems lacking.

\section{9. 인턴2 (하대리에게) 요즘엔 회사도 사회배려자 전형 같은 게 있나요?} yo-jeum-en hoe-sa-do sa-hoe-bae-lyeo-ja jeon-hyeong gat-eun ge iss-na-yo? (H: gently formal)

Intern 2: (To Ha Daeri) These days, is there any charity in the hiring practices at the company?

10. 이상현(off) 좀 건방진 말이지만요, 솔직히 기분 나빠요. jom geon-bang-jin mal-i-ji-man-yo, sol-jig-hi gi-bun na-ppa-yo. (H: gently formal) I Sanghyeon: It might be a bit cocky, but I'm offended

\section{1. 일동 (보면)}

Il Dong: (Looking at him)

Script: (Yoon-Jung 2014)

**translation note: getting into college is very difficult in South Korea, so the college entrance exam and high school are often considered more stressful than University.

Between co-workers of different rank

In Misaeng (미생), characters of lower rank usually speak in one of the formal forms of speech to higher ranked characters. These characters often converse in the 
heavily formal -습니다 ((seu)b-ni-da) speech style or the gently formal -요 (oyo/ayo)

style. In comparison, the hierarchically superior characters often speak to their subordinate colleagues in the gently formal -요 (oyo/ayo) or the informal soft or plain casual speech styles. In this excerpt, the intern, Baek Gi, is considering quitting his job and plans to not come into work. Yu Daeri, the team boss, is aware of Baek Gi's plans and indirectly asks him to do work for the team anyways.

\section{Episode 9: Scene 38 (team boss-intern; different rank)}

1. 유대리 어, 강대리님 오늘 오지? 언제 들어 온 대? eo, gang-dae-li-nim o-neul o-ji? eon-je deul-eo on dae? (IF: plain casual) Yu Daeri: Uh, intern are you coming in today? When are you coming?

2. 백기 오늘 못 오신다는데요. o-neul mos o-sin-da-neun-de-yo. (F: gently formal)

Baek Gi: I can't come in today.

3. 유대리 (난감) 어? 못 와? 아.. eo? mos wa? A.. (IF: plain casual) Yu Daeri: (uncaring) Eh? Not coming? Ah...

4. 백기 무슨 일이신데요..? mu-seun il-i-sin-de-yo..? (F: gently formal) Baek Gi: What's going on..?

5. 유대리 EPC TF 건 예산안 변경된 거, 오늘 재무팀에서 추가결재 해야 된다고 각 팀별로 제출하래. 철강팀 것도 준비해야 할 텐데.. EPC TF geon ye-san-an byeon-gyeong-doen geo, o-neul jae-mu-tim-e-seo chu-ga-gyeol-jae hae-ya doen-da-go gag tim-byeol-lo je-chul-ha-lae. cheol-gang-tim geos-do jun-bi-hae-ya hal ten-de.. (IF: plain casual)

Yu Daeri: The Ministry of Planning and Budget said that it will be revised by the Ministry of Finance and Economy, and that the financial team should be additionally approved by the financial team today.Maybe we should prepare for the steel team...

6. 백기 (딱히 할 맏이 없어 본다)...

Baek Gi: (seems to have nothing special to say)

7. 유대리 장백기씨가 진행 할 수 있나? 별 거 아닌데. jang-baeg-gi-ssi-ga jin-haeng hal su iss-na? byeol geo a-nin-de. (IF: plain casual) Yu Daeri: Can you do this? It's not a big deal.

8. 백기 (살짝 놀란다) 네? ne?

Baek Gi: Huh?

9. 유대리 전체 보고서는 강대리가 다하고 갔으니까, 그거 결재문서에 맞게 한 다섯 장 정도로 요약하고, 변경 예산안이랑 타임테이블 줄여서 넣으면 돼 jeon-che bo-go-seo-neun gang-dae-li-ga da-ha-go gass-eu-ni-kka, geu-geo gyeol-jae-mun-seo-e 
maj-ge han da-seos jang jeong-do-lo yo-yag-ha-go, byeon-gyeong ye-san-an-i-lang ta-im-te-i-beul jul-yeo-seo neoh-eu-myeon dwae (IF: plain casual)

Yu Daeri: Since the entire report was carried out by Kang daha, a total of five pages were collected, and the revised budget and time tables should be reduced.

Script: (Yoon-Jung 2014)

These patterns are further demonstrated in the interactions between Team three's

team boss (Oh Sang Sik) and Team three's employee (Dong Sik) in episode 3, scene 44.

\section{Episode 3: Scene 44 (manager-employee; different rank)}

1. 동식 과장님.. gwa-jang-nim..

Dong shik: Manager...

2. 상식 (버력) 넌 무슨 일을 그 따위로 해!!! neon mu-seun il-eul geu tta-wi-lo hae!!! (IF: soft casual)

Sang shik: (suddenly) How could have performed so poorly!!

3. 동식 (숙이는) 죄송합니다. joe-song-hab-ni-da. (F: heavily formal) Dong shik: (bows head) I'm sorry.

4. 그래 (급히 들어 온다)

GeuRae: (heard coming in)

5. 상식 확인, 또 확인하라고 몇 번을 말했어?!! hwag-in, tto hwag-in-ha-la-go myeoch beon-eul mal-haess-eo?!! (IF: soft casual)

Sang shik: How many times did I tell you all to check it out?!!

6. 동식 (숙인 채) 죄송합니다.... joe-song-hab-ni-da. (F: heavily formal) Dong shik: (bows) I'm sorry.

7. 상식 후.... 아니지. 아니다. 그걸 검토해서 결재한 건 나니까 내 책임이지 hu.... a-ni-ji. a-ni-da. geu-geol geom-to-hae-seo gyeol-jae-han geon na-ni-kka nae chaeg-im-i-ji (IF: soft casual)

Sang shik: No... no, no. No. It's my responsibility to review it and approve it.

8. 동식 아닙니다. 제가, a-nib-ni-da. Je-ga, (F: heavily formal) Dong shik: No. l...

9. 상식 실수라곤 도통 모르던 놈이 어쩌다 그랬어? 중국 딜레이건으로 정신 없었 던 거 알아. 근데 여러 번 애기했잖아. 너 나 둘만 하는 일이기 때문에

일당백이어야 한다고! sil-su-la-gon do-tong mo-leu-deon nom-i eo-jjeo-da geu-laess-eo? jung-gug dil-le-i-geon-eu-lo jeong-sin eobs-eoss deon geo al-a. geun-de yeo-leo beon yae-gi-haess-janh-a. neo na dul-man ha-neun il-i-gi ttae-mun-e il-dang-baeg-i-eo-ya han-da-go! (IF: soft casual)

Sang shik: What happened to you who doesn't make mistakes often? I know you've been distracted by tasks for the China project, but l've told you many times that because only you and I working alone on this, we have to take care as much as we can!!

10. 동식 죄송... 합니다. joe-song... hab-ni-da. (F: heavily formal)

Dong shik: Im... sorry.

Script: (Yoon-Jung 2014) 
In this exchange, the superior team manager, Sang sik, speaks to his employee in entirely informal Korean speech styles. Conversely, Dong sik employs the heavily formal -습니다 ((seu)b-ni-da) speech style in response to Sang sik's statements. Important to note is that in this exchange, Sang sik is expressing anger to Dong sik and, as a result, Dong sik switches his speak to the highest formal speech style. In previous exchanges, Dong sik speaks the gently formal -요 (oyo/ayo) ending more frequently with Sang sik than he speaks the -습니다 ((seu)b-ni-da) formal speech style. As the subordinate employee, Dong sik is expected to use one of the two formal speech styles as used by other characters throughout the drama. Dong sik changes his speech style to a higher version of the speech to indicate further respect and deference to his superior, Sang sik.

\section{Request/favor strategies}

Between co-workers of the same rank

In instances of request, all character's regardless of relationship were shown using higher speech styles than usual. This pattern is particularly notable in speech between co-workers of equal rank, as their speech is usually in the same speech style to indicate their hierarchical equality (Yoon-Jung 2014). In this excerpt, intern Yeong I is requesting offering to do a favor for Geu Rae by tying his tie for him. Geu Rae tries to refuse the help politely and switches from gently formal speech to heavily formal speech in line 10 to indicate his respect.

\section{Episode 2: Scene 4 (intern-intern;same rank)}

1. 영이 인턴은 복장준수 꽤 철저해요. In-teon-eun bog-jang-jun-su kkwae cheol-jeo-hae-yo. (F: gently formal) Yeong I: An intern is quite strict with dress.

\section{2. 그래 네? Ne? (무슨 소린가 싶어...) (F: gently formal)} Geu Rae: Pardon?(What do you mean ......)
3. 영이
(삐져나온 넥타이를 본다) 
Yeong I: (looks at the bulging tie)
4. 그래
아.. A... (당황해서 주머니에 쑤셔 넣으며) 맬 줄을 몰라서요. mael jul-eul mol-la-seo-yo. (F: gently formal)
Geu Rae: Oh...(surprised, places tie in pocket)I don't know how to tie it.
5. 영이 (다시 앞을 본다) .... Yeoung I: (looking forward again)...
6. 그래 Geu Rae: ....
7. 영이 … 줘 보세요.... jwo bo-se-yo. (F: gently formal) Yeoung l: ... give it to me.
8. 그래 (깜짝, 본다) Geu Rae: (surprised)
9. 영이 (손을 내민다) Yeoung I: (reaches hand out)
10. 그래 (머뭇거리며) 괜찮습니다. Gwaen-chanh-seub-ni-da. (F: heavily formal) Geu Rae: (pause) it's okay.

11. 영이 주세요. 매 드릴게요. ju-se-yo. mae deu-lil-ge-yo. (F: gently formal) Yeoung I: give it to me. I'll tie it for you.

Script: (Yoon-Jung 2014)

In the majority of this script and throughout the drama, Geu Rae speaks to Yeoung I in the gently formal speech style. However, after Yeoung I offers to tie Geu Rae's tie for him, Geu Rae switches the most formal speech style, heavily formal. By saying "it's okay" (관찬습니다) in the heavily formal speech style, Geu Rae is politely responding to Yeoung I's offer with his own offer of rejection. Simultaneously, Geu Rae's use of speech style indicates a higher form of respect towards Yeoung I and appreciation for her offer.

\section{Refusal strategies}

\section{Between co-workers of a different rank}

As previously discussed, the majority of the relationships in Misaeng (미생 )

follow a clear, observable hierarchy. Throughout the script, superior employees generally speak in the gently formal or informal soft or plain casual speech styles. Equally, inferior employees often speak in one of the formal speech styles, either employing the heavily formal -습니다 ((seu)b-ni-da) ending or the gently formal -요 (oyo/ayo) ending (Misaeng 
2014). In some instances, employees lower in the workplace hierarchy need to refuse their superiors. However, due to the neo-Confucian values of kibun and inhwa, the employees should avoid direct refusal of superiors (Lee 2012).

Therefore, these employees must find a way to refuse their superiors without upsetting the hierarchy or upsetting the kibun or inhwa of their boss. In these instances, the employee may choose to lower their speech style but still use polite, formal speech. Prior to the next scene, Sang Sik has rejected and disrespected Geu Rae and in this scene he is sub.. This is visible in the following scene, in which the intern Geu Rae subtly refuses to be further disrespected by his team boss Sang Sik.

\section{Episode 2: Scene 37 (intern-team boss; different rank)}
1. 상식
업무 시간에 어딜 가는 거야? eob-mu si-gan-e eo-dil ga-neun geo-ya?
(IF: plain casual)
Sang Sik: Where are you going during work hours?

2. 그래 Geu Rae:...

3. 상식 내 말 안 들려? nae mal an deul-lyeo? (IF: soft casual) Sang Sik: Are you ignoring me?
4. 그래
혼자라서... hon-ja-la-seo-tss... Geu Rae: Because I'm alone...
5. 그래 할 수 있는 일이 없네요... hal su iss-neun il-i eobs-ne-yo-tss (F: gently formal) Geu Rae: There's nothing I can do...
6. 상식 뭐? mwo? (IF: plain casual) Sang Sik: What?
7. 상식 (기가 막혀) 너 지금 뭐하자는 거야?! neo ji-geum mwo-ha-ja-neun geo-ya?! (IF: plain casual) Sang Sik: What are you doing now?
8. 그래 (본다) 혼자 하는 일이 아니라면서요? 회사 일은. hon-ja ha-neun il-i a-ni-la-myeon-seo-yo? hoe-sa il-eun. (F: gently formal) Geu Rae: You have said work, it should not be done alone.
9. 상식 Sank Sik: (...)
10. 그래 친구가 없냐고 하셨죠? 혼자 쓴 일기 같다구. 잘 보셨습니다. 네, 혼자 해야 했죠. 혼자 싸우고 결과도 책임도 혼자 져야 했죠. chin-gu-ga eobs-nya-go ha-syeoss-jyo? hon-ja sseun il-gi gat-da-gu. jal bo-syeoss-seub-ni-da. ne, hon-ja hae-ya haess-jyo. hon-ja ssa-u-go gyeol-gwa-do chaeg-im-do hon-ja jyeo-ya haess-jyo. (F:




\section{gently formal)}

Geu Rae: You've told me that I have no friends? look like a diary which is written alone.

Yes, I had to do it myself. I had to fight by myself alone, and I know it is my responsibility.

11. 상식 너 지금 뭐하는, neo ji-geum mwo-ha-neun, Sang Sik: You what are you,

12. 그래(o.I) 그래서 혼자하지 않는 법을 모틉니다. 모르니까, 가르쳐주실 수 있잖아요 기회를 주실 수 있잖아요. geu-lae-seo hon-ja-ha-ji anh-neun beob-eul mo-leub-ni-da. mo-leu-ni-kka, ga-leu-chyeo-ju-sil su iss-janh-a-yo gi-hoe-leul ju-sil su iss-janh-a-yo. (F: gently formal)

Geu Rae: So I don't know how to do this alone. I don't know, but you can teach me. You can give me a chance.

13. 상식

기회에도 자격이 있는 거다. gi-hoe-e-do ja-gyeog-i iss-neun geo-da. (IF:

plain casual)

Sang Sik: You have to be qualified even to have an opportunity.

14. 그래 무슨 자격이요? mu-seun ja-gyeog-i-yo? (F: gently formal) Geu Rae: What qualification?

15. 상식몰라서 물어? mol-la-seo mul-eo? (IF: soft casual) Sang Sik: You don't know?

16. 그래 묻습니다. 제가 학벌이 짭은 것 때문이라면 mud-seub-ni-da. je-ga hag-beol-i jjalb-eun geos ttae-mun-i-la-myeon (F: heavily formal) Geu Rae: I ask. If it's because I have a lacking academic background

17. 상식(o.I) 여기 사람들이 이 빌딩 로비 하나 밥기 위해 얼마나 많은 계단을 오르락 내리락 했는 줄 알아? yeo-gi sa-lam-deul-i i bil-ding lo-bi ha-na balb-gi wi-hae eol-ma-na manh-eun gye-dan-eul o-leu-lag nae-li-lag haess-neun jul al-a? (IF: soft casual)

Sang Sik: Do you know how many people have climbed the stairs up and down to even step foot in this lobby? (Metaphor meaning: Do you know how many people put in work in order to get into this company? Do you think you have put in as much effort?)

Script: (Yoon-Jung 2014)

\section{Style switching and other linguistic strategies}

Sarcasm and face-insulting speech between client and employee

Speech style switching can indicate a number of situations: a change in mood,

changes in relationship status, or to indicate distance or closeness with the listener (Brown 2013). In this scene, team three manager Sang Sik is meeting with a client who he regards as a close friend. The client, Hyeong Cheol, has intentionally made him wait for an extensive period of time before meeting with Sang Sik. Hyeong Cheol then turns down Sang Sik's proposal and when Sang Sik is surprised, Hyeong Cheol switches from the soft 
casual speech style to the heavily formal speech style (Yoon-jung 2014). This switch

indicates distance and results in embarrassment and discomfort for Sang Sik.

\section{Episode 6: Scene 16 (teamboss-client; different rank)}

1. 상식 (밝아지고) 어! 왔어? (앉으라고 손짓하며) 얼마 안 기다렸어. 바쁘지? eo! wass-eo? eol-ma an gi-da-lyeoss-eo. Ba-ppeu-ji? (IF: soft casual, plain casual)

Sang Sik: (quickly) Oh! You came? (sits down and while bowing) not long after. You're busy, right?

2. 형철 (상식의 앞에 놓고 앉으면)

Hyeong Cheol: (sits next to Sang Sik)

3. 상식 (보며) 아, 그래. 바쁘지? 바로 시작할까? a, geu-lae. ba-ppeu-ji? ba-lo si-jag-hal-kka? (IF: soft casual, plain casual)

Sang Sik: (while looking) Ah, okay. You are busy right? Should we start quickly?

4. 형철 보내 준 자료 검토 해 봤는데 자료가 너무 부족해. 설비도 이해가 안 되고, 수익룰도 애매하고.. bo-nae jun ja-lyo geom-to hae bwass-neun-de ja-lyo-ga neo-mu bu-jog-hae. seol-bi-do i-hae-ga an doe-go, su-ig-lyul-do ae-mae-ha-go.. (IF: plain casual)

Hyeong Cheol: I checked the report you sent me but it's too short. I don't understand the facilities. Profit is also uncertain.

5. 상식 (가방에서 서너 개의 서류 꺼내 내밀면서) 그래서 내가 더 보완해 왔어. (서류 하나씩 짚어 주며) 설비, 라면 종류, 수익배분울 이거는 (하면서 적 극적으로 설명을 하려고 붙어 앉는다.) geu-lae-seo nae-ga deo bo-wan-hae wass-eo. seol-bi, la-myeon jong-lyu, su-ig-bae-bun-yul i-geo-neun (IF: soft casual)

Sang Sik: (takes a couple of further documents out of bag) So, I've brought more... (Hands papers over to show to Hyung Chul) Facilities, instant noodles, and profit sharing rates(they sit together in order to explain dramatically)

6. 형철 (시큰둥) 내가 지금 볼 시간은 없고, nae-ga ji-geum bol si-gan-eun eobs-go,

Hyeong Cheol: (uncaring) I don't have time to look at it now,

7. 상식 (얼른 말 받아) 아. 내가 설명해 줄게. 금방 파악 할 수 있을 거야. (IF: plain casual) a. nae-ga seol-myeong-hae jul-ge. geum-bang pa-ag hal su iss-eul geo-ya.

Sang Sik: (whispers). Oh. Let me explain. You'll understand soon enough.

8. 형철 (피식 비옷으며) 어이 오상식 일 참 쉽게 할라 그러네. eo-i o-sang-sig il cham swib-ge hal-la geu-leo-ne. (IF: familiar style)

Hyeong Cheol: (Giggles) Ah- Oh Sang Sik you try to work easily.

9. 상식 (멈칫)

Sang Sik: (taken aback)

10. 그래 (순간 당황해서 상식의 얼굴 보는데)

Geu Rae: (narrator's voice: it's embarrassing)

11. 형철 (냉랭) 오상식 과장님, 검토하고 타당성 여부 확인해서 연락 할게요.

o-sang-sig gwa-jang-nim, geom-to-ha-go ta-dang-seong yeo-bu hwag-in-hae-seo yeon-lag hal-ge-yo. (F: gently formal)

Hyeong Cheol: (Coldly) Section Chief Mr. Oh Sang Sik, after I review and check its validity, I'll be in touch.

12. 상식 (당항해서) 어... 그... 그래. eo... geu... geu-lae. (IF: soft casual) Sang Sik: (puzzled) Uh.. Oh.. Ok. 


\section{3. 형철 (힐끗 보면)}

Hyeong Cheol: (glancing)

\section{4. 상식 (얼른) 그러십시오. geu-leo-sib-si-o. (F: heavily formal)}

Sang Sik: (quickly) Yes do as you please

\section{Conclusion}

Through analysis of Misaeng, I found that characters in hierarchical relationships used various speech styles based on their social location. In general, characters in Misaeng with higher hierarchical positions most frequently spoke in lower or informal speech styles to their subordinates. Comparatively, subordinates almost always spoke in one of the formal speech styles to their superiors. Individuals separated by one level of hierarchy usually spoke the gently formal style to superiors whereas those separated by two or more levels usually spoke the heavily formal. Co-workers with the same rank particularly favored the gently formal or one of the informal speech styles depending on the intimacy level of their relationship. Individuals in the same hierarchical position usually spoke in the same style. If there were different styles used by these same rank characters it often demonstrated tension or a request between the characters.

However, hierarchy was only partially responsible for indicating the characters' language choice. This analysis found that the speaker's intention and the situation surrounding the conversation had a major impact on the character's speech style choice. Characters often changed their speech styles mid-conversation to indicate tension, refusal, request, favor, distance, or disrespect. As demonstrated in the "refusal strategies" section, some inferior characters would indirectly refuse their superiors by speaking in the lower honorific form. Equally, as shown in the "request/favor strategies" section, when making requests even characters of the same hierarchical level would often raise their speech style 
to a higher style of speech. Formal speech was often used to indicate respect, as shown in the "regular speech patterns" section, but this form could also be used to indicate distance and cause embarrassment as in the "speech style switching" excerpt.

In all of the analyzed episodes of Misaeng (episodes 1-11), there were strict hierarchical patterns which changed based on more than the hierarchical relationship between the speaker and listener. Situation, hierarchical location, and speaker intention all played key roles in the character's language choice. This thesis demonstrates that, in the context of Misaeng, a character's speech style in the Korean language is much more complicated than merely indicating respect and hierarchy. Although speech style choice is most often discussed in the context of politeness, speech style may be used to indicate distance and even disrespect, as indicated in the "speech style switching" section. These findings could provide further information about the nature and usage of speech styles in Korean for native Korean speakers and Korean linguists. Furthermore, this study could help second language Korean learners understand how to use speech styles like a native speaker by showing insight into the complexity of speech style usage. 


\section{$\underline{\text { References }}$}

Agha, Asif.

1998. "Stereotypes and registers of honorific language."

Language in Society. Volume 27-02: 151.

Brown, Lucien.

2010. "Politeness and second language learning: The case of Korean speech styles." Journal of Politeness Research. Language, Behaviour, Culture. Volume 6, Number 2.

Brown, Lucien.

2012. "Teaching 'casual' and/or 'impolite' language through multimedia: the case of non-honorific panmal speech styles in Korean." Language, Culture and Curriculum. 26(1): 1-18.

Brown, Lucien.

2013. “"Mind your own esteemed business': Sarcastic honorifics use and impoliteness in Korean TV dramas." Journal of Politeness Research. 9(2): 159-186.

Brown, L., Winter, B., Idemaru, I., and Sven Grawunder.

2014. "Phonetics and politeness: Perceiving Korean honorific and non-honorific speech through phonetic cues.” Journal of Pragmatics. 66: 45-60.

Brown, Lucien.

2015. "Honorifics and Politeness." The Handbook of Korean Linguistics. John Wiley \& Sons, Inc. 17: 303- 319. 
Brown, L., and Jaehoon Yeon.

2015. "Varieties of Contemporary Korean." The Handbook of Korean Linguisitics. 26 (1): 459-476.

Byon, Andrew S.

2006. "Korean Cultural Values in Request Behaviors." In Korean Language in Culture and Society. Ho-min Sohn, Pp. 174- 188. University of Hawaii Press.

Cannon, Anneliese, and Alissa Blair.

2014. "Dramatic Data: The Possibilities of Ethnodramatic Writing for Understanding the Experiences of English Learners in Community College Settings." Critical Inquiry In Language Studies. 11-4: 307-333.

Chesebro, James W.

2003. "Communication, values, and popular television series- A twenty-five year assessment and final conclusions.” Communication Quarterly. 51-4: 367-418.

Cho, Sungdai.

2006. "Linguistic Structures of Korean." In Korean Language in Culture and Society. Ho-min Sohn, Pp. 236- 248. University of Hawaii Press.

Choo, Miho.

2006. "The Structure and Use of Korean Honorifics." In Korean Language in Culture and Society. Ho-min Sohn, Pp. 132- 145. University of Hawaii Press.

Hwang, Juck Ryoon.

2009. "'Deference' vs 'politeness' in Korean Speech." International Journal of the Sociology of Language. Volume 1990. 82: 41-56.

Hwang, Shin Ja J.

2015. "Korean Discourse Structure." The Handbook of Korean Linguistics. John Wiley \& Sons, Inc. 16: 287-302.

Jin, B. and Seongjung Jeong.

2010. "The impact of Korean television drama viewership on the social perceptions of single life and having fewer children in married life." Asian Journal of Communication. 20(1): 17-32.

Kim, Hye Ri Stephenie. 
2010. "A high boundary tone as a resource for a social action: The Korean sentence-ender -ta." Journal of Pragmatics. 42: 3055-3077.

Kwon, N. and Patrick Sturt.

2016. "Attraction Effects in Honorific Agreement in Korean." Frontiers in Psychology. 7. 1302:1-12.

Lee, Choong Y.

2012. "Korean Culture and Its Influence on Business Practice in South Korea." The Journal of International Management Studies. 7(2): 184- 191.

Oh, Sun-Young.

2010. "Invoking categories through co-present person reference: The case of Korean conversation." 42: 1219-1242.

Park, Jae-Eun.

2016. "Turn-taking in Korean conversation.” Journal of Pragmatics. 99: 62-77.

Park, Mae-Ran.

1990. Conflict avoidance in social interaction: A sociolinguistic comparison of the Korean and Japanese honorific systems. In Hajime Hoji, ed., Japanese/Korean Linguistics. 111-28. Stanford: CSLI Publications.

Park, Young-Yae.

2006. "Politeness in Conversation in Korean: The Use of -nunde." In Korean Language in Culture and Society. Ho-min Sohn, Pp. 164- 173. University of Hawaii Press.

Seo, Y.N., Leather, P., and Iain Coyne.

2012. "South Korean culture and history: The implications for workplace bullying." Aggression and Violent Behavior. 17: 419-422.

Seth, Michael J.

2016. Military Rulers and Mongol Invaders, 1170 to 1392. In A Concise History of Korea: From Antiquity to Present. Pp 111-134. Lanham, Maryland: Rowman \& Littlefield.

Seth, Michael J. 
2016 The Neo-Confucian Revolution and the Choson State, 1392 to the 18th Century. In A Concise History of Korea: From Antiquity to Present. Pp 135-166. Lanham, Maryland: Rowman \& Littlefield.

Yi, So Young L.

2015. "Sociophonetic Variations in Korean Constituent Final "-Ko" and "-To." n.p.: ProQuest LLC, 2015.

Yoon, Kyung-Eun.

2010. "Questions and responses in Korean conversation." Journal of Pragmatics. 42: 2782-2798.

Yoon-jung, Jung.

2014. “An Incomplete Life; 미생.” Dolby Digital 2.0: tvN. Language: Korean. 